\title{
CAAX Prenyl Protease 2
}

National Cancer Institute

\section{Source}

National Cancer Institute. CAAX Prenyl Protease 2. NCI Thesaurus. Code C115012.

CAAX prenyl protease 2 (329 aa, $\sim 36 \mathrm{kDa}$ ) is encoded by the human RCE1 gene. This protein is involved in the removal of prenylated peptides from proteins. 